\title{
MODERN TAX SYSTEM OF UKRAINE: POSSIBILITIES OF REFORMING?
}

\author{
LIUDMILA DEMYDENKO
}

https://doi.org/10.35945/gb.2017.03.018

PhD in Economics,

Associated Professor of Taras Shevchenko National University of Kyiv, Ukraine

KEYWORDS: TAX SYSTEM OF UKRAINE, TAX REFORM, TAX POLICY

Purpose is to find the main point of tax system modernization as a part of fiscal policy in Ukraine.

Methods of research. The article includes a set of general scientific methods and approaches including systemic, structural, dialectical, comparative, logical which allowed to form a conceptual unity of research.

The subject of research is tax system modernization in the context of economy development and integration into EU.

Results of research. Establishment of Ukraine's tax system began in the early 90's of XX century with adoption of the Law of Ukraine "On Taxation System" (1991). Article 67 of the Constitution of Ukraine declares that everyone is obliged to pay taxes and charges in the manner and in the amount established by law [1].

The modern tax system was forming during years of independence of Ukraine and passed several stages:

Stage 1-1991-1996 - establishment of the national tax system;

Stage 2 - 1997-2003 - establishment of a tough model of the tax system with repressive nature;

Stage 3-2004-2010 - stage of perfection of the national tax system;

Stage 4 - from 2010 to present day - stage of institutionalization of Ukraine's tax system. Each stage was characterized by adoption of a number of laws and regulations (laws, strategies, concepts) determining basic taxation rules as well as strategic and medium-term perspective as to development of the national tax system [2].

Adoption of the Tax Code of Ukraine (TCU) marked a stage of institutionalization of the tax system. TCU determines list of taxes and charges payable in Ukraine and procedure of their administration; payers of taxes and charges, their rights and responsibilities; competences of regulatory authorities, powers and responsibilities of officials during exercise of tax control, as well as liability for tax legislation violation [3]

With adoption of the Tax Code of Ukraine in 2010 list of taxes was decreased from 28 to 18 national, from 14 to 5 local taxes, and in 2014 there was further reduction in their number: to 7 national and 4 local (table 1 ) .

Table 1. National and local taxes and charges as of 01.01 .2018

\begin{tabular}{|c|c|}
\hline National taxes and charges & Local taxes and charges \\
\hline $\begin{array}{l}\text { 1. } \text { Corporate tax; } \\
\text { 2. Personal income tax; } \\
\text { 3. Value added tax; } \\
\text { 4. Excise tax; } \\
\text { 5. Environmental tax; } \\
\text { 6. } \text { Rental charges including: } \\
\text { - } \quad \text { on subsurface use for mineral } \\
\text { production } \\
\text { - on subsurface use for } \\
\text { purposes not related to } \\
\text { mineral production } \\
\text { on use of radio frequency } \\
\text { resource of Ukraine } \\
\text { - on special water usage } \\
\text { - on special forest exploitation } \\
\text { on transportation of oil, } \\
\text { natural gas and ammonia } \\
\text { through the territory of } \\
\text { Ukraine } \\
\text { 7. Customs duties }\end{array}$ & $\begin{array}{l}\text { 8. Estate tax including: } \\
\text { - land charges } \\
\text { - transport tax } \\
\text { - property tax } \\
\text { 9. Single tax. } \\
\text { Local charges include: } \\
\text { 10. Charges on places } \\
\quad \text { for parking vehicles } \\
\text { 11. Tourist charges. }\end{array}$ \\
\hline
\end{tabular}

Source: compiled by the author on the basis of TCU

In 2015, the government planned to carry out tax reform and a new model of the tax system was developed and presented for broad discussion. Furthermore, an alternative version of the reform of the tax system was created and registered in the Parliament (Verkhovna Rada) by the Committee of the Verkhovna Rada of Ukraine for tax and customs policy was created alternative (table 2 ).

Table 2 Main tax rates in Ukraine, 2016-2018

\begin{tabular}{|l|c|c|c|c|}
\hline & PIT & UST & $\begin{array}{c}\text { Corporate } \\
\text { profit tax }\end{array}$ & VAT \\
\hline $\begin{array}{l}\text { Government } \\
\text { project 2015 }\end{array}$ & $20 \%$ & 20 & 20 & 20 \\
\hline $\begin{array}{l}\text { Committee } \\
\text { project 2015 }\end{array}$ & $10 \%$ & 20 (no limit) & 15 & 15 \\
\hline $\begin{array}{l}\text { Compromise } \\
\text { option } \\
\text { approved 2016 }\end{array}$ & $18 \%$ & $\begin{array}{l}22 \text { (limit 25 } \\
\text { subsistence } \\
\text { minimum) }\end{array}$ & 18 & $20 ; 7 ; 0$ \\
\hline 2017 approved & $18 \%$ & $\begin{array}{c}22 \text { (limit 25 } \\
\text { subsistence } \\
\text { minimum) }\end{array}$ & 18 & $20 ; 7 ; 0$ \\
\hline 2018 approved & $18 \%$ & $\begin{array}{c}22 \text { (limit 15 } \\
\text { minimum wage) }\end{array}$ & 18 & $20 ; 7 ; 0$ \\
\hline
\end{tabular}

Source: compiled by the author on the basis of TCU 
As a result, it was possible to reach a compromise on the basis of improving the current tax system with adjustment of tax rates: PIT reduced to $18 \%$, UST- $22 \%$, VAT and corporate tax- rates have not changed.

In addition to personal income tax, military tax was introduced in 2014 in the amount of $1.5 \%$ of payroll budget as a temporary measure to support conduct of antiterrorist operation in the East.

Unified Social Tax (UST) was imposed by the Law of Ukraine "On the collection and registration of a single contribution to the compulsory state social insurance". Its rate was significantly reduced for employers to $22 \%$ of payroll budget, at the same time UST from employees was canceled in 2016.

The calculation uses Unified Social Tax limit - 44,050 UAH (approx. 1660 USD) for December 2017 - 25 subsistence minimum.

For 2018, maximum value of the base of the calculation of the UST payment - the maximum amount of income insured person per month, equal to fifteen sizes of minimum wage established by law, which is charged a single contribution [ 4 ].

It was crisis in 2014 that forced to introduce military tax, taxation of passive income: interest income received from placing funds on deposit bank accounts, VAT on medicines is introduced (previously they were exempt from VAT), in 2015 marginal rate of personal income was increased to $20 \%$.

Conclusions. The institutional environment favorable to business and enterprises have a significant impact on the development of the economy and the solution of many social issues. Conducting institutional changes in developing a tax system of Ukraine will increase welfare, living standards of the population and overcome poverty.

The socially oriented model of the country's economy should combine innovative and fiscal leverage that provides the development of small business as the basis for the formation of a wealthy middle class.

It is necessary to use tax policy instruments to support the development of small businesses, such as a simplified accounting and reporting system, lower tax rates, improve information and consulting services for small businesses, and introduce a fairer taxation of their income.

Tax regulations for small business development should be aimed at increasing the volume of their financial resources, improving the quality of factors of production, their contribution to GDP, the development of intellectual capital.

\section{REFERENCES:}

1. Constitution of Ukraine. Available at: http: //zakon3.rada.gov.ua/laws/show/254\%D0\%BA/96-\%D0\%B2\%D1\%80 (accessed 8 March 2017).

2. Nesterenko O., Demydenko L. (2017) Tax system of Ukraine: a neoliberal challenge or latent shifts, Scientific Letters of Academic Society of Michal Baludansky. Volume 5, No.2.-p.78-82.

3. Tax Code of Ukraine. Available at: http://zakon3.rada.gov.ua/laws/show/2755-17 (accessed 8 March 2017).

4. Law of Ukraine "On the collection and registration of a single contribution to the compulsory state social insurance" (2018). Available at: http://zakon5.rada.gov.ua/laws/show/2464-17. 


\title{
MODERN TAX SYSTEM OF UKRAINE: POSSIBILITIES OF REFORMING?
}

LIUDMILA DEMYDENKO

https://doi.org/10.35945/gb.2017.03.018

PhD in Economics,

Associated Professor of Taras Shevchenko National University of Kyiv, Ukraine

\author{
KEYWORDS: TAX SYSTEM OF UKRAINE, TAX REFORM, TAX POLICY
}

\section{SUMMARY}

The article deals with the drafts of two versions of tax reform, which were represented in 2015 by the Ministry of Finance of Ukraine and by the Committee of the Verkhovna Rada of Ukraine for tax and customs policy. The authors have represented the types of tax reforms on principles and methods of implementation tax policy in Ukraine. Insignificant positive changes were created in the tax system due to the adoption of compromise amendments to the tax legislation. A substantial reduction of the Unified Social Tax (UST) can be considered an important contribution for improving the business climate in Ukraine. It was concluded to provide radical tax reforms in the nearest future. 